The Merging of Disciplines:

New Directions in Pure, Applied, and Computational Mathematics 


\title{
The Merging of Disciplines: New Directions in Pure, Applied, and Computational Mathematics
}

\author{
Proceedings of a Symposium \\ Held in Honor of Gail S. Young \\ at the University of Wyoming, August 8-10, 1985. \\ Sponsored by the Sloan Foundation, the National Science Foundation, and \\ the Air Force Office of Scientific Research
}

\author{
Edited by \\ Richard E. Ewing \\ Kenneth I. Gross \\ Clyde F. Martin
}

With 25 Illustrations

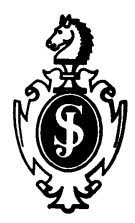

Springer-Verlag

New York Berlin Heidelberg

London Paris Tokyo 
Richard E. Ewing

Department of Mathematics

University of Wyoming

Laramie, WY 82071, USA

Kenneth I. Gross

Department of Mathematics

University of Wyoming

Laramie, WY 82071, USA
Clyde F. Martin

Department of Mathematics

Texas Tech University

Lubbock, TX 79409, USA

Library of Congress Cataloging in Publication Data

Symposium on New Directions in Applied and Computa-

tional Mathematics (1985: University of Wyoming)

The merging of disciplines.

"Proceedings of the Symposium on New Directions

in Applied and Computational Mathematics."

1. Mathematics-Congresses. 2. Young, Gail S.

I. Ewing, Richard E. II. Gross, Kenneth I.

III. Martin, Clyde. IV. Title.

$\begin{array}{llll}\text { QA1.S8993 } 1985 & 510 & 86-24848\end{array}$

(C) 1986 by Springer-Verlag New York Inc.

All rights reserved. No part of this book may be translated or reproduced in any form without written permission from Springer-Verlag, 175 Fifth Avenue, New York, New York 10010, USA. The use of general descriptive names, trade names, trademarks, etc. in this publication, even if the former are not especially identified, is not to be taken as a sign that such names, as understood by the Trade Marks and Merchandise Marks Act, may accordingly be used freely by anyone.

Permission to photocopy for internal or personal use, or the internal or personal use of specific clients, is granted by Springer-Verlag New York Inc. for libraries and other users registered with the Copyright Clearance Center $(\mathrm{CCC})$, provided that the base fee of $\$ 0.00$ per copy, plus $\$ 0.20$ per page is paid directly to CCC, 21 Congress Street, Salem. MA 01970, U.S.A. Special requests should be addressed directly to Springer-Verlag New York, 175 Fifth Avenue, New York, NY 10010, USA.

$96353-7 / 86 \$ 0.00+.20$

Printed and bound by R.R. Donnelley \& Sons, Harrisonburg, Virginia. 
Dedicated to the memory of Irene $V$. Young

October 6, 1925 - October 4, 1985 


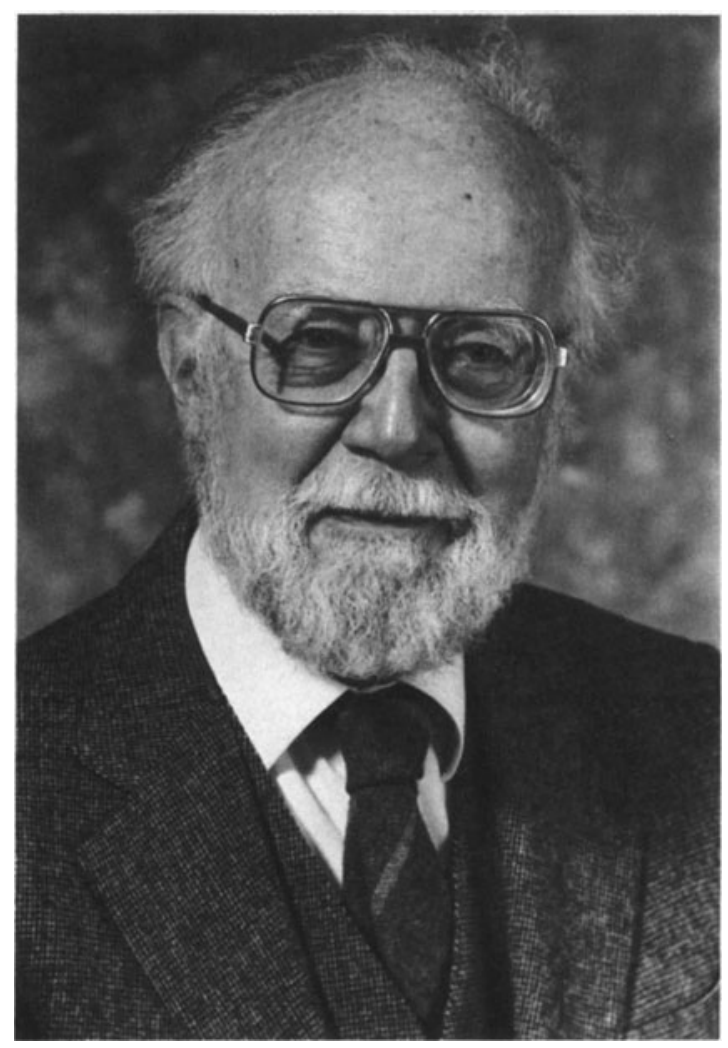

GAIL S. YOUNG 


\section{PREFACE}

This volume is the Proceedings of the symposium held at the University of Wyoming in August, 1985, to honor Gail Young on his seventieth birthday (which actually took place on October 3,1985 ) and on the occasion of his retirement.

Nothing can seem more natural to a mathematician in this country than to honor Gail Young. Gail embodies all the qualities that a mathematician should possess. $\mathrm{He}$ is an active and effective research mathematician, having written over sixty papers in topology, $n$-dimensional analysis, complex variables, and "miscellanea." He is an outstanding expositor, as his fine book Topology, written with J. G. Hocking (Addison Wesley, 1961), amply demonstrates. He has a superlative record in public office of outstanding, unstinting service to the mathematical community and to the cause of education. But what makes Gail unique and special is that throughout all aspects of his distinguished career, he has emphasized human values in everything he has done. In touching the lives of so many of us, he has advanced the entire profession. Deservedly, he has innumerable friends in the mathematical community, the academic community, and beyond.

It is tempting to describe Gail Young today as the archetypal "elder statesman" of mathematics; but that description misses the point that Gail never strikes one as an elder! He is far too vigorous, too enthusiastic, too involved to qualify for any title suggesting withdrawal and dispassionate reflection. Our respect for Gail certainly includes an appreciation of his wisdom; but we have appreciated his wisdom for decades. He has not had to wait till now to achieve it, nor have we waited till now to evidence our recognition of it.

It is appropriate to list here certain significant details of Gail's life and career. But such a recital, impressive though it may be, is still quite inadequate to capture the flavor and the true meaning of Gail's role in American-and world-mathematics over the past thirty years. The whole man whom we are privileged to know, to respect and to love is not to be found in the details about to be presented. Gail Young was 
born in Chicago, Illinois, on October 3, 1915. He went as an undergraduate to Tulane University in 1935 and transferred to the University of Texas for his senior year. While at Tulane he was profoundly influenced by H. E. Buchanan, who started many mathematicians on their careers, and by Bill Duren, to whom Gail gives credit for introducing him to rigorous mathematics. Gail remained at Texas to do his Ph.D. under R. L. Moore, obtaining the degree in 1942. He taught at Purdue University until 1947 and then at the University of Michigan through 1959, attaining the rank of full professor. He then returned to Tulane University where he stayed until 1970 , serving as chairman for the years 1963-68. He was at Rochester University from 1970 to 1979 , most of the time as chairman, moved to Case Western Reserve University in 1979 and to a visiting position at the University of Wyoming in 1981, where he has remained as vigorous, active, and effective as ever.

Gail's services to the mathematical community and to the cause of education through his work within various professional organizations, are too numerous to list individually. Of particular significance are his terms as President of the MAA (1969-70); his chairmanship of the Teacher Training Panel of CUPM (1964-68); his membership of the AMS Committee on Employment and Educational Policy (197274) and the Committee on Women in Mathematics (1974-76); his membership of the Council of AAAS $(1968-70,1975)$ and his chairmanship of the mathematics section (1981-84); and his membership of the NAS-NRC Committee on Applications of Mathematics (1964-67). Yet this catalog of outstanding service omits so much which most of us would be proud to claim as our own principal contributions.

The simple truth is that everything Gail has done has been well done, useful and important. And he has done an enormous lot! Let me, then, desist from the unwonted objectivity of this listing of Gail's work as researcher, teacher and campaigner for better education, and adopt the frankly subjective mode appropriate to a friend and admirer.

Gail was, by all accounts, an outstanding student. The story is told of Gail returning to calculus class after an absence of several weeks (that was during the Depression and Gail had been unable to pay the tuition fees!). On his first day back there was a test from which Buchanan would gladly have excused Gail. Gail insisted on taking the test and obtained the grade of 100, though others found the test awesomely difficult. Buchanan, reporting Gail's success and the failure of others whom he did not name, asked "What does that show?" After a short silence, one student replied, "I beg your pardon, Dr. Buck, but it shows that you ruined us."

Many of Gail's students have testified to his remarkable qualities as a teacher, at all levels. He did not use the "Moore" method of his own teacher, but neither was he a lecturer in the traditional mold. He showed his students how to do mathematics-how to pose questions and to try to answer them, how to develop and exploit geometric insight. In his view of mathematics as consisting of the search for questions it might 
be profitable to try to solve, he much resembles the great Swiss topologist Heinz Hopf. Moreover, he shares with Hopf the ineffable quality of unbounded kindness towards all genuinely interested in mathematics and trying to learn. As one of his students has said, "When he was with one of his students, he was $100 \%$ with that student... He knew the state of mind of his students, and could be encouraging when things weren't going well mathematically or personally."

My own association with Gail began in 1964 when he persuaded me to join the Teacher Training Panel of CUPM. I joined that panel knowing little of its duties because I was aware of wanting to work with Gail-just as I had started to study algebraic topology in 1946, knowing little of the subject, because I wanted to work with Henry Whitehead. Both men possessed to a remarkable degree the ability to convey the conviction - fully vindicated by subsequent experience-that to work with them would be to do something which was important, probably hard, but certainly fun. Throughout my many associations with Gail, I have always been struck by the sheer massive good sense of the man. Gail is possessed of a universal intelligence and sensitivity which are by no means guaranteed by possession of the quality of cleverness. Testimony to that good sense is provided by the anecdote told by Henry Pollak relating to their visit to Africa in 1968 to evaluate the effects of the Africa Mathematics Program (usually called the Entebbe Program). In Addis Ababa, Gail and Henry had an interview with a high official of the Ethiopian Ministry of Education. At the end, Gail quietly suggested to Henry that he be left alone for a few minutes with the official. It transpired that the official was making a grant application to the Ford Foundation and required some help in drafting the proposal. The official realized that Gail was the person to provide that help-and Gail understood the loss of face that would be involved if more than he and the official were present.

Further testimony to Gail's good sense, and to his total honesty and great integrity, is provided by the record of his chairmanship of the Tulane department in the years 1963-68. For various evident reasons this was not a propitious time to try to build a strong research department at a university in the South, but Gail was remarkably successful. Ed Dubinsky refers to his "openness, reasonableness and concern," and has described how Gail wooed him to Tulane by writing him a letter in which he described his philosophy in running a department, offered a salary which he acknowledged to be too low, and then explained how it was arrived at. One suspects that it needed a combination of Gail's honesty and Ed's idealism to have created this match!

No tribute to Gail would be complete without mention of his wonderful wife Irene, who was the Administrative Assistant of the Tulane department. Theirs was an ideal marriage, a true partnership. Our sympathies go out to Gail who must face his retirement deprived of her loving companionship; but we find some comfort in recalling her pleasure in observing the outpouring of respect, admiration, and 
affection for Gail at the banquet in his honor held in conjunction with the Laramie Conference.

My final word should be this: Gail, though now retired, is still an active member of our community and our profession-long may it be so, for we need him for his wisdom and we enjoy him for himself.

\section{PETER HILTON}

with the assistance of

Ray Cannon, Ed Dubinsky, Bill Duren, Ken Gross, J. G. Hocking,

Burton Jones, Henry Pollak and Sanford Segal 


\section{CONTENTS}

Preface by Peter Hilton vii

Schedule of Symposium Events xiii

Introduction $\quad \mathbf{x v}$

Computer Graphics Applications in Geometry: "Because the 1 light is better over here"

Thomas F. Banchoff

Modelling and Algorithmic Issues in Intelligent Control 15

Christopher J. Byrnes

Global Observability of Ergodic Translations on Compact Groups

Lance Drager and Clyde Martin

Mathematical Modeling and Large-Scale Computing in Energy

and Environmental Research

Richard E. Ewing

Symbolic Manipulation

Harley Flanders

Some Unifying Concepts in Applied Mathematics

Ismael Herrera

Teaching and Research: The History of a Pseudoconflict

Peter Hilton

Stochastic Population Theory: Mathematical Evolution of a

Genetical Model

Kenneth J. Hochberg

Combinatorics and Applied Mathematics

Daniel J. Kleitman

Applied Logic

Anil Nerode

Pure and Applied Mathematics from an Industrial Perspective

H. O. Pollak

Letter Values in Multivariate Exploratory Data Analysis

Donald St. P. Richards and Rameshwar D. Gupta 
Newton's Method Estimates from Data at One Point Steve Smale

Error Bounds for Newton's Method under the Kantorovich As197 sumptions

Tetsuro Yamamoto

Panel Discussion: Implications for Undergraduate and Graduate Education in Mathematics

Sol Garfunkel

Epilogue by Gail Young 


\section{SYMPOSIUM \\ on \\ NEW DIRECTIONS IN APPLIED \\ AND COMPUTATIONAL MATHEMATICS}

August 8-10, 1985

Thursday, August 8

Opening remarks by Dr. Donald Veal

President of the University of Wyoming

\section{First Session}

HENRY O. POLlaK, AT\&T Communications

"Pure and applied mathematics from an industrial perspective"

Christopher BYRnes, Arizona State University

"Recent results in adaptive control: An opportunity for intelligent and artificially intelligent control"

\section{Second Session}

ANIL NeRODE, Cornell University

"The impact of logic and recursive functions on computational sciences"

Ismael Herrera, Universidad Nacional Autonoma de Mexico

"Some unifying concepts in applied mathematics"

\section{First Session for Contributed Papers}

Harley Flanders, Florida Atlantic University

"Symbolic manipulation"

TETSURO YAMAMOTO, University of Wisconsin-Madison

"Error bounds for Newton's method under the Kantorovich assumptions"

KenNeth J. HoChBERG, Case Western Reserve University

"New directions in mathematical population biology" 


\section{Third Session}

Peter J. Hilton, State University of New York at Binghamton

"Teaching and research - the history of a pseudo-conflict"

Clyde F. MARTin, Texas Tech University

"Observability in dynamical systems"

\section{Fourth Session}

JACOB T. SCHWARTZ, Courant Institute

"Problems of shape recognition"

DANIEL J. KLEITMAN, MIT

"Combinatorics and applications, a mutual enrichment"

\section{Second Session for Contributed Papers}

DONALD RICHARDS, University of North Carolina

"Letter values in multivariate exploratory data analysis"

FranK HARARY, University of Colorado, Boulder

"Graph theoretic models in anthropology, biology and chemistry"

G. EltoN Graves, Rose-Hulman Institute of Technology

"Computer graphics in numerical analysis and differential equations courses"

Saturday, August 10

\section{Fifth Session}

RICHARD E. EWING, University of Wyoming

"Mathematical modeling and large-scale computing in energy and environmental research"

ThOMAS F. BANCHOFF, Brown University

"Computer graphics applications in geometry: 'because the light is better over here""

\section{Sixth Session}

STEPHEN SMALE, University of California at Berkeley "When and how fast can Newton's method be expected to converge?"

\section{Panel Discussion}

"Implications for undergraduate and graduate education in mathematics"

WILlIAM L. DUREN, JR., University of Virginia

SOL GARFUNKEL, COMAP

PETER J. HILTON, SUNY at Binghamton

GAIL S. YOUNG, University of Wyoming

KENNETH I. GROSS, University of Wyoming (moderator)

Banquet in honor of Gail Young 


\section{INTRODUCTION}

The articles that follow form the Proceedings of a truly remarkable symposium, held at the University of Wyoming in August, 1985, on the theme "New Directions in Applied and Computational Mathematics." The result was successful beyond anyone's expectation. The spirit of communication, enthusiasm, and cooperation was pervasive, and the breadth and depth of topics was spectacular. All who attended came away with a rich and enjoyable experience. We hope that the reader of this Proceedings will also.

The focus of the Symposium was on the mutual interaction among pure mathematics, applied mathematics, and computer science that is rapidly and dramatically changing the nature of all three disciplines. Indeed, when the editors were in college and graduate school in the late fifties, the sixties, and the early seventies, there was

seldom a difficulty in determining who were the applied mathematicians and who the pure. Now, even the purest of mathematics has found profound and influential applications, and applied problems have generated new thrusts in areas that have always been regarded as pure. The main instrument in this coalescence has been the computer.

A glance at the list of authors and titles reveals the unique flavor of the Symposium and this volume. A number of distinguished mathematicians, whose careers and whose research illustrate the unity of mathematics, were asked to share their insights into this phenomenon and to describe their own contributions. Thus, the articles which appear in this volume, which also includes several contributed papers, are diverse in both scope and nature. Some are expositions of the cultural context of a field of mathematics, a concept, or a perspective. Others present important current research. Their quality and clarity is exceptional. At the very least, the articles that appear here should dispel forever the notion that there are two kinds of mathematics, and they should reinforce the idea that it is impossible to predict the source of the next breakthrough. The labels "pure" and "applied" are no longer applicable to mathematics or to mathematicians. 
It is most appropriate that this volume is in honor of Gail Young, who long ago realized that mathematics should not be separated from its applications. That is one of many examples of his wisdom, from which all three of us have benefitted.

It should be noted that the current Symposium is a sequel to an earlier one in 1981, organized by Gail and Peter Hilton, with a similar title, "New Directions in Applied Mathematics." That conference also had as its theme the rapport of pure and applied mathematics. It emphasized the fact that modern techniques are of critical importance in applications. Missing from that conference was the computer, as the organizers were not yet ready to define the role of the computer in its interaction with mathematics and applications. To fill that gap was a motivation of this current Symposium.

As we learn from the articles herein, much has transpired since the earlier conference. No doubt the same statement will be applicable to this volume a few years hence. The rapid developments alluded to at the outset of this introduction will continue to bring together more areas that were previously thought unrelated. That can be seen already. For example, who would have predicted at the time this symposium was organized that the von Neumann algebras which arose decades ago in quantum physics and had just recently become a major tool in knot classification, would-because of the resultant improvements in classification-excite great interest among microbiologists concerned with the knotting of DNA? This would be a major topic were the Symposium held today. Thus, the editors see a clear need to continue this series of symposia periodically as new developments dictate.

To close on a personal note, it is a pleasure to express our appreciation to all who helped make the Symposium and this Proceedings a success. We are deeply indebted to the speakers, authors, and participants. Special thanks go to a number of individuals. Sol Garfunkel played a major role in proposal preparation. The administrative assistance of Sharon Distance in organizing the Symposium, and Lois Kline and Paula Sircin in preparation of the Proceedings was invaluable. In particular, the excellence of Paula's typing is evidenced in the camera ready copy that is before you. The support, encouragement, and suggestions by Dr. Walter Kaufmann-Buhler, Editor for SpringerVerlag, have been of great benefit to us. Finally, none of this would have been possible without the financial support of the sponsors. The Editors wish to record their gratitude for the generosity of the Sloan Foundation, the National Science Foundation, and the Air Force Office of Scientific Research.

RICHARD E. EWING

KENNETH I. GROSS

ClYDE F. MARTIN

Laramie, Wyoming

May 25, 1986 